\title{
Dynamic changes in terrestrial net primary production and their effects on evapotranspiration
}

\author{
Zhi Li ${ }^{1}$, Yaning Chen ${ }^{1}$, Yang Wang ${ }^{2}$, and Gonghuan Fang ${ }^{1,3}$ \\ ${ }^{1}$ State Key Laboratory of Desert and Oasis Ecology, Xinjiang Institute of Ecology and Geography, Chinese Academy of \\ Sciences, Urumqi, China \\ ${ }^{2}$ College of Pratacultural and Environmental Sciences, Xinjiang Agricultural University, Urumqi, China \\ ${ }^{3}$ Department of Geography, Ghent University, Ghent, Belgium \\ Correspondence to: Yaning Chen (chenyn@ms.xjb.ac.cn)
}

Received: 19 February 2016 - Published in Hydrol. Earth Syst. Sci. Discuss.: 17 March 2016

Accepted: 22 May 2016 - Published: 6 June 2016

\begin{abstract}
The dramatic increase of global temperature since the year 2000 has a considerable impact on the global water cycle and vegetation dynamics. Little has been done about recent feedback of vegetation to climate in different parts of the world, and land evapotranspiration (ET) is the means of this feedback. Here we used the global $1 \mathrm{~km}$ MODIS net primary production (NPP) and ET data sets (2000-2014) to investigate their temporospatial changes under the context of global warming. The results showed that global NPP slightly increased in 2000-2014 at a rate of $0.06 \mathrm{PgC} \mathrm{yr}^{-2}$. More than $64 \%$ of vegetated land in the Northern Hemisphere (NH)

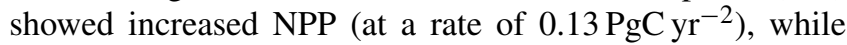
$60.3 \%$ of vegetated land in the Southern Hemisphere $(\mathrm{SH})$ showed a decreasing trend (at a rate of $-0.18 \mathrm{PgC} \mathrm{yr}^{-2}$ ). Vegetation greening and climate change promote rises of global ET. Specially, the increased rate of land ET in the $\mathrm{NH}$ $\left(0.61 \mathrm{~mm} \mathrm{yr}^{-2}\right)$ is faster than that in the $\mathrm{SH}\left(0.41 \mathrm{~mm} \mathrm{yr}^{-2}\right)$. Over the same period, global warming and vegetation greening accelerate evaporation in soil moisture, thus reducing the amount of soil water storage. Continuation of these trends will likely exacerbate regional drought-induced disturbances and point to an increased risk of ecological drought, especially during regional dry climate phases.
\end{abstract}

\section{Introduction}

Organizations such as the Intergovernmental Panel on Climate Change (IPCC) and the World Meteorological Organization (WMO) have reported that the past decade was the warmest on record. Global warming indicates a general acceleration or intensification of the global hydrological cycle and thus an alteration in the process of evapotranspiration (ET) (Wentz et al., 2007; Douville et al., 2013), with implications for the response and mutual feedback of ecosystem services (Field et al., 2007; Jung et al., 2010; Davie et al., 2013). Yet how global vegetation is responding to the changing climate is not well established.

Terrestrial net primary production (NPP) can be defined as the amount of photosynthetically fixed carbon available to the first heterotrophic level in an ecosystem, and links terrestrial biota with atmospheric systems (Beer et al., 2010; Chen et al., 2012; Potter et al., 2012; Pan et al., 2014). From 1982 to 1999 , climatic changes enhanced plant growth globally, especially in the northern middle and high latitudes (Nemani et al., 2003); this was followed in 2000-2009 by a droughtinduced reduction in global NPP (Zhao and Running, 2010). Gang et al. (2015) projected the dynamics of NPP in response to future anticipated climate changes in the 2030s, 2050s, and 2070s, and found that global NPP would show an increasing trend. In particular, NPP at high latitudes in the Northern Hemisphere (NH) would likely be more sensitive to future climate change. The interaction of water, temperature, and radiation has imposed complex and varying limitations on vegetation activities in different regions of the 
world. Several studies have indicated that climate constraints (e.g., increasing temperatures and solar radiation) are relaxing (Nemani et al., 2003). However, clear data on spatiotemporal variations and attributes in global terrestrial NPP within the context of high variability warming are still lacking.

Meanwhile, little has been done about recent feedback of vegetation to climate in different parts of the world (Zhi et al., 2009), and ET is the means of this feedback. A recent study suggested that vegetation productivity influences albedo and emissivity, which then strongly regulate global climate (Chapin et al., 2011). Shen et al. (2015) reported that, in contrast to the Arctic region (i.e., positive feedback to warming), increased vegetation activity may attenuate daytime warming by enhancing ET as a cooling process on the Tibetan Plateau. Zhang et al. (2015) investigated how climate change and recent vegetation greening promote multidecadal rises of global ET (1982-2013), while an anomalous drought between 2000 and 2009 led to reduced NPP in the Southern Hemisphere (SH) (Zhao and Running, 2010). However, little observational evidence exists to demonstrate vegetation feedback on climate across different global geographical units.

Having a clear understanding of the land's biophysical feedback to the atmosphere is crucial if we are to simulate regional climate accurately (Tian et al., 2000). In our study, we investigated the following three major points of interest: (1) whether the high variability temperature of the past decade continued to increase NPP, or if different climate constraints were at play; (2) why NPP variations in the Northern and Southern hemispheres respond differently to climate changes; and (3) what the spatiotemporal variation of NPP is, and what its effects are on ET.

\section{Data and methodology}

\subsection{Data}

The monthly grid data of the temperature and precipitation series from 2000 to 2014, with a spatial resolution of $0.5^{\circ}$, were collected from the Climatic Research Unit (Univertisy of East Anglia Climatic Research Unit, 2015). The radiation and soil moisture data series were issued by the Global Land Data Assimilation System (GLDAS-1), with a spatial resolution of $0.25^{\circ}$ (http://gdata1.sci.gsfc.nasa.gov/daac-bin/G3/ gui.cgi?instance_id=GLDAS025_M). The depths of the four soil layers are $0-10,10-40,40-100$, and $100-200 \mathrm{~cm}$. The quality of the GLDAS data set was assessed against available observations from multiple sources (Zhang et al., 2008; Chen et al., 2015).

The monthly data of the Palmer Drought Severity Index (PDSI), with a spatial resolution of $2.5^{\circ}$, was available at http://www.cgd.ucar.edu/cas/catalog/climind/pdsi. $\mathrm{html}$. As an indicator of land-surface moisture conditions, PDSI has been widely used for the routine monitoring and assessment of global and regional drought conditions. Gen- erally, a lower PDSI implies a drier climate. The global dry areas were defined as PDSI $<-3.0$, while the wet areas were defined as PDSI $>+3.0$ (Dai et al., 2004).

We used the Global Land Cover Characterization data from the International Geosphere-Biosphere Program (IGBP) in 2000 (http://nsidc.org/data/ease/ancillary. html\#igbp_classes), along with MODIS in 2000 and 2013 (http://modis.gsfc.nasa.gov/data/dataprod/mod12.php).

From these data, a routinely integrated classification of land use/cover change (LUCC) characteristics was obtained based on the feature fusion processes.

The global $1 \mathrm{~km}$ NPP data sets (2000-2014) are from MOD17. NPP estimations are typically model-based and biogeochemical, and are generated from a larger set of simulated $\mathrm{C}$ fluxes between the atmosphere and terrestrial ecosystems (Ito, 2011). A better agreement of MODIS and terrestrial NPP estimates allows the use of MODIS in large-scale estimates (Neumann et al., 2015).

The MODIS evapotranspiration data sets (2000-2014) from MOD16 are estimated using the Mu et al. (2011) improved ET algorithm over Mu et al.'s (2007) previous paper. Based on the energy-balance theory and the PenmanMonteith equation, the required MODIS data inputs for the ET algorithms include daily meteorology (temperature, actual vapor pressure, and incoming solar radiation) remotely sensed land cover, FPAR/LAI, and albedo (Friedl et al., 2010; Myneni et al., 2002).

We unified the spatiotemporal resolution of these data from different sources, based on resampling (nearest neighbor interpolation) and reclassification techniques, and combined the data from the different source data sets to form comprehensive records.

\subsection{Methods}

\subsubsection{NPP algorithm}

Net primary production estimations are typically modelbased and biogeochemical, generated from a larger set of simulated $C$ fluxes between the atmosphere and terrestrial ecosystems (Ito, 2011). The global $1 \mathrm{~km}$ MODIS NPP data sets from 2000 to 2014 are from MOD17. A better agreement of MODIS and terrestrial NPP estimates allows for the use of MODIS in large-scale estimates (Neumann et al., 2015). The algorithm calculates annual NPP as

$\mathrm{NPP}=\sum_{i=1}^{365}\left(\mathrm{GPP}-R_{\mathrm{m}}\right)-R_{\mathrm{g}}$.

Similarly, the algorithm calculates daily GPP as

$\mathrm{GPP}=\varepsilon_{\max } \times \mathrm{SW}_{\mathrm{rad}} \times \mathrm{FPAR} \times f \mathrm{VPD} \times f T_{\min }$.

$R_{\mathrm{m}}$ is the maintenance respiration, which is a function of daily average temperature $\left(T_{\text {avg }}\right)$ : 


$$
\begin{aligned}
& R_{\mathrm{m}}=Q_{10}^{\left(\frac{T_{\mathrm{avg}}-20}{10}\right)} \\
& Q_{10}=3.22-0.046 \times T_{\mathrm{avg}} .
\end{aligned}
$$

Therefore,

$$
\begin{aligned}
\mathrm{NPP} & =\sum_{i=1}^{365}\left(\mathrm{GPP}-R_{\mathrm{m}}\right)-R_{\mathrm{g}} \\
& =\sum_{i=1}^{365}\left(\mathrm{GPP}-R_{\mathrm{m}}\right)-0.25 \times \mathrm{NPP},
\end{aligned}
$$

which means

$$
\begin{aligned}
\mathrm{NPP}= & 0.8 \times \sum_{i=1}^{365}\left(\mathrm{GPP}-R_{\mathrm{m}}\right), \\
& \text { where } \sum_{i=1}^{365}\left(\mathrm{GPP}-R_{\mathrm{m}}\right) \geq 0
\end{aligned}
$$

$\mathrm{NPP}=0, \quad$ where $\sum_{i=1}^{365}\left(\mathrm{GPP}-R_{\mathrm{m}}\right)<0$,

where $\varepsilon_{\max }$ is the maximum light use efficiency, $\mathrm{SW}_{\text {rad }}$ is shortwave downward solar radiation (of which $45 \%$ is photosynthetically active radiation - PAR), FPAR is the fraction of PAR being absorbed by the plants, $f$ VPD and $f T_{\min }$ are the reduction scalar from high daily time vapor pressure deficit and low daily minimum temperature $\left(T_{\min }\right)$, respectively, and annual growth respiration $\left(R_{\mathrm{g}}\right)$ is a function of annual maximum leaf area index (LAI). Zhao and Running (2010) modified the calculations by assuming that growth respiration is approximately $25 \%$ of NPP.

\subsubsection{ET and PET algorithm}

The MODIS evapotranspiration data sets are estimated using the Mu et al. (2011) improved ET algorithm over Mu et al.'s (2007) previous paper. Based on the energy-balance theory and the Penman-Monteith equation, the required MODIS data inputs ET algorithms, including daily meteorology (temperature, actual vapor pressure, and incoming solar radiation) remotely sensed land cover, FPAR/LAI, and albedo (Friedl et al., 2010; Myneni et al., 2002). The output variables include evapotranspiration (ET), latent heat flux (LE), potential ET (PET), potential LE (PLE), and quality control (ET_QC).

\subsubsection{Trend analysis}

To further discern the trends of yearly NPP and ET, we examined linear trend estimations on a per-pixel basis to establish a linear regression relationship between variables $\left(x_{i}\right)$ and time $\left(t_{i}\right)$. The regression coefficient $(b)$ is

$$
b=\frac{n \times \sum_{i=1}^{n} x_{i} t_{i}-\sum_{i=1}^{n} x_{i} \sum_{i=1}^{n} t_{i}}{n \times \sum_{i=1}^{n} t_{i}^{2}-\left(\sum_{i=1}^{n} t_{i}\right)^{2}} .
$$

\subsubsection{Partial correlation analysis}

This method is used to describe the relationship between two variables while removing the effects of several other variables. The partial correlation of $x_{1}$ and $x_{2}$ is adjusted for a third variable of $y$, at a significance level of 0.05 by the $T$ test:

$r_{x_{1} x_{2}} \cdot y=\frac{r_{x_{1} x_{2}}-r_{x_{1} y} r_{x_{2} y}}{\sqrt{\left(1-r_{x_{1} y^{2}}\right)\left(1-r_{x_{2} y^{2}}\right)}}$.

\section{Results and analysis}

\subsection{Spatiotemporal variations in global terrestrial NPP and their effects on ET}

The spatial patterns of global NPP from 2000 to 2014 showed a steadily decreasing trend from the equator to the Arctic and Antarctic (Fig. 1c). Overall, the interannual series of NPP increased moderately at a rate of $0.06 \mathrm{PgC} \mathrm{yr}^{-2}$ over the past 15 years, and also shows different changes in the Northern and Southern hemispheres. While NPP in most parts of the NH increased (Fig. 1a), it decreased in most parts of the SH (Fig. 1b). Specifically, in the NH, $64 \%$ of vegetated land area experienced increased NPP, including large areas of North America, western Europe, India, and eastern China. Regions with decreased NPP include eastern Europe and higher latitudes of central and west Asia. In the SH, decreased NPP accounted for about $60.3 \%$ of vegetated land area, mainly concentrated in South America, south Africa, and western Australia. Furthermore, in the equatorial regions, Amazon rainforests had significantly decreased NPP, whereas African rainforests experienced an increasing trend (Fig. 1c). Because tropical rainforest NPP accounts for a large proportion of global NPP, decreases in SH NPP partially counteracted the increases in NH NPP.

When we combined global LUCC characteristics, the results showed that shrubland has the greatest potential increasing trend of NPP $\left(16.5 \mathrm{gC} \mathrm{m}^{-2} \mathrm{yr}^{-1}\right)$ compared to other biomes, followed by grassland $\left(12.5 \mathrm{gC} \mathrm{m}^{-2} \mathrm{yr}^{-1}\right)$. This may be related to the expansion of woody vegetation over the past 15 years. In the Arctic tundra (Hughes et al., 2006) and lower latitudes in arid environments (Chen et al., 2014; Li et al., 2015), experimental studies provided clear evidence that climate warming is sufficient to account for the expansion of shrubs. 

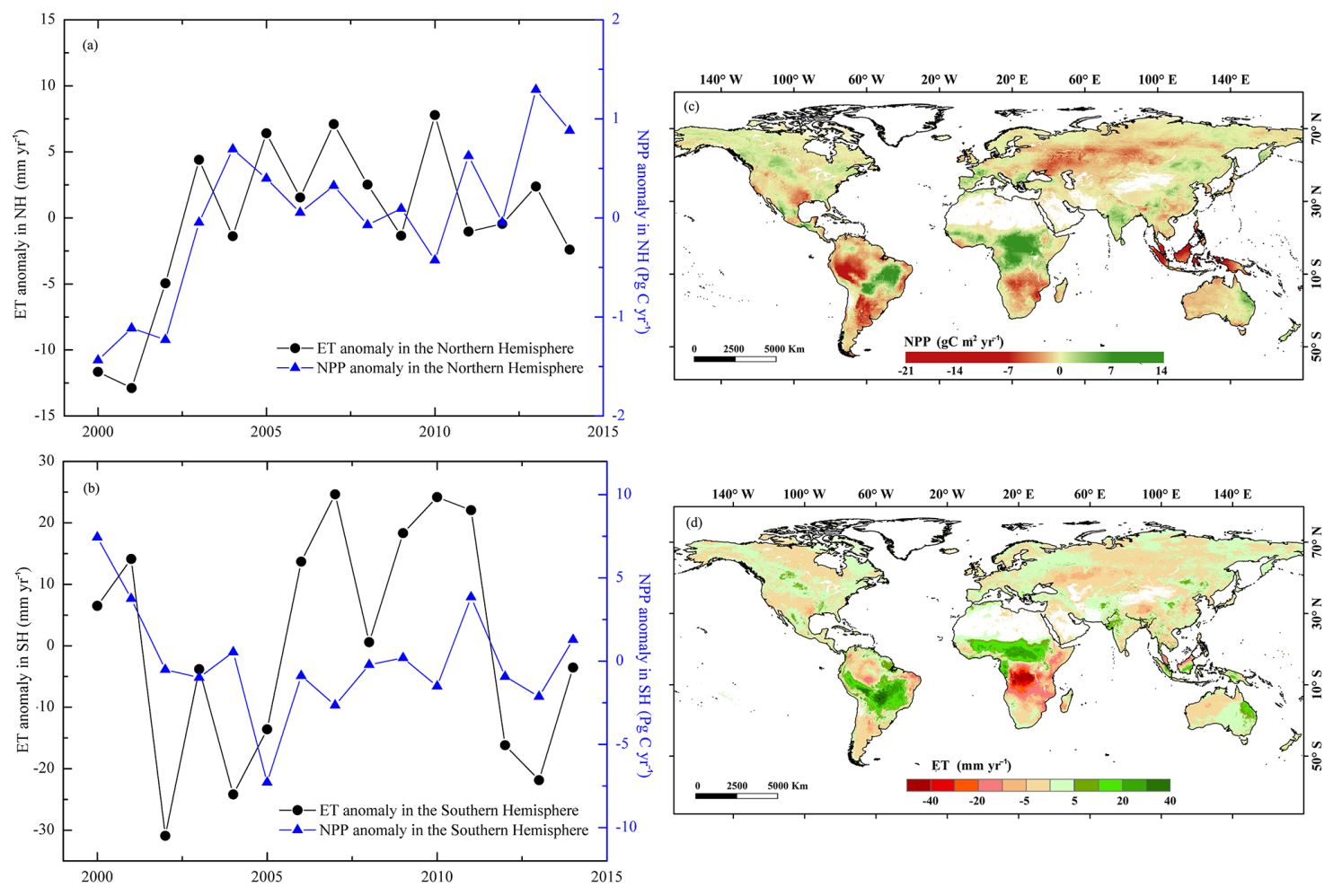

Figure 1. Temporospatial variations in global terrestrial NPP and ET from 2000 to 2014. (a) Interannual variations of NPP and ET in the Northern Hemisphere (NH). (b) Interannual variations of NPP and ET in the Southern Hemisphere (SH). (c) Spatial pattern of NPP trend from 2000 to 2014. (d) Spatial pattern of ET trend from 2000 to 2014.

Changes in vegetation albedo and emissivity exert feedback on climate, which is especially obvious in ET (Field et al., 2007). The viability of vegetation cover can substantially modulate available surface energy and partition that energy into sensible and latent heat fluxes (Matsui et al., 2005). Increased vegetation productivity and climate change may promote the rises of global ET. The average mean of estimated global annual ET is $518.6 \mathrm{~mm} \mathrm{yr}^{-1}$, with an interannual trend of $0.46 \mathrm{~mm} \mathrm{yr}^{-2}$. Figure 1 shows that the spatiotemporal changes of global ET are consistent with NPP variations, especially in the NH. Furthermore, where their association is less than that in the NH, NPP and ET in the SH have much higher variability. Specially, the increased rate of land ET in the NH $\left(0.61 \mathrm{~mm} \mathrm{yr}^{-2}\right)$ is faster than that in the $\mathrm{SH}\left(0.41 \mathrm{~mm} \mathrm{yr}^{-2}\right)$. Anomalous warming indicates a general prospective acceleration or intensification of the global hydrological cycle and thus an alteration in the process of ET, but dry conditions have caused a reduction in vegetation productivity and a near cessation of ET growth in the SH. The spatial inconsistency in the SH mainly occurred near the equator, e.g., southern African rainforests (Fig. 1b and d). These regions have high values of average annual precipitation and stronger variability of precipitation than elsewhere, causing greater changes to ET and its components (landsurface evaporation, canopy evaporation, and transpiration).
In the context of warming, places where the interannual variability of NPP is small, the ET component of land-surface evaporation will increase. In contrast, in areas with large interannual variability of NPP, such as shrubland and grassdominant regions, the ET components of land-surface evaporation will decline and transpiration increase. Vegetation generally promotes land-atmosphere water exchange via transpiration through a biological process, changing soil moisture conditions and affecting the land-atmosphere feedback.

\subsection{Controlling factors for NPP variations}

Water, temperature, and radiation interact to impose complex and varying limitations on vegetation activities in different parts of the world, thus also affect ET partly. To understand why NPP variations in the Northern and Southern hemispheres respond differently to climates, we first estimated the spatial trends of climatic control factors and then analyzed the complex multiple climatic constraints to plant growth. A comprehensive interpretation of interactive climatic controls on plant productivity showed that water, temperature, and radiation are the key factors affecting vegetation growth. Globally, growth was most strongly limited by water availability on $40 \%$ of the Earth's vegetated surface, while temperature limitations exerted the main controlling influence on $33 \%$ of the surface, and radiation on $27 \%$ (Nemani et al., 2003). 


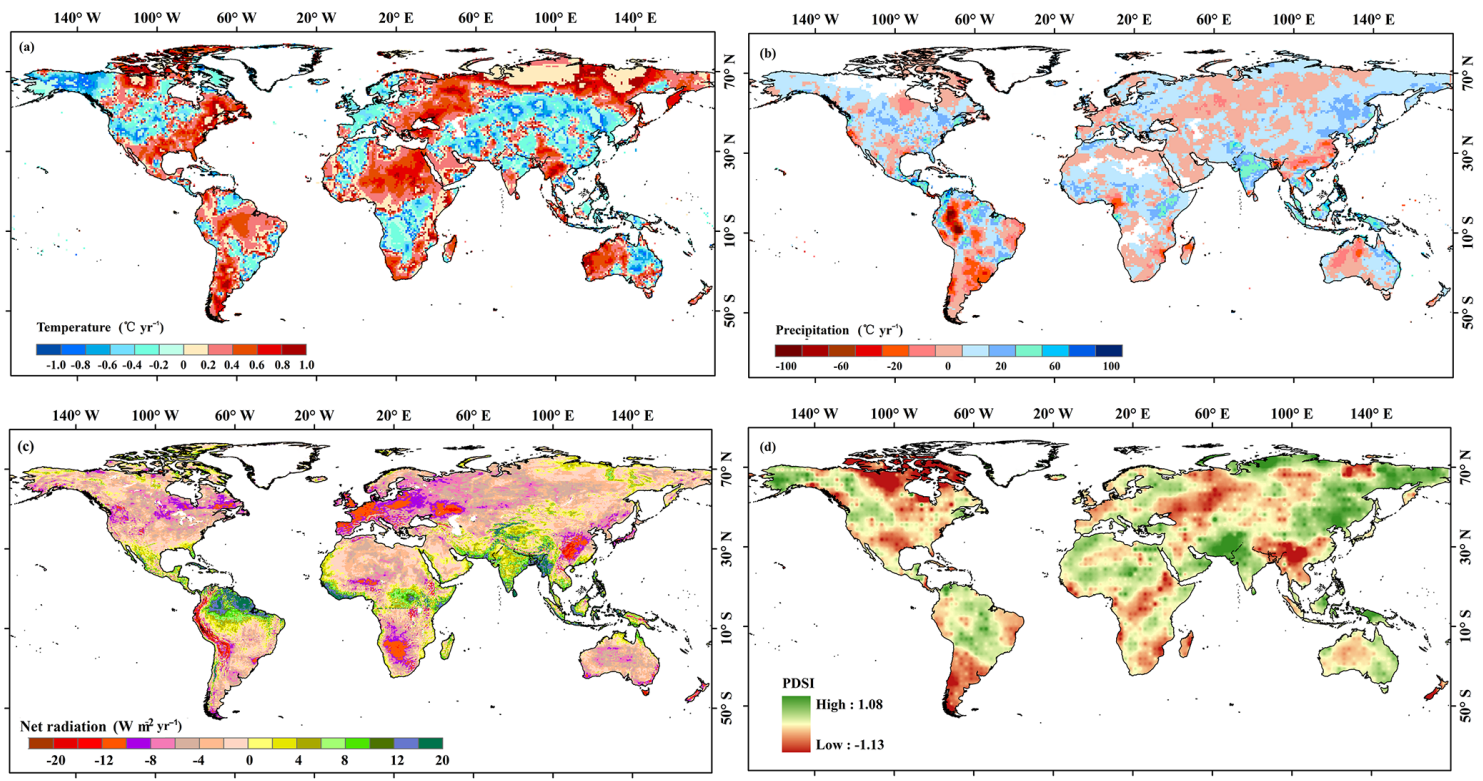

Figure 2. Trends of air temperature $(T)$, precipitation $(P)$, net radiation $\left(R_{\mathrm{n}}\right)$, and Palmer Drought Severity Index (PDSI) from 2000 to 2014.

From 2000 to 2014 , overall trends of average annual temperature $\left(0.007^{\circ} \mathrm{C} \mathrm{yr}^{-2}\right)$ and precipitation $\left(0.84 \mathrm{~mm} \mathrm{yr}^{-2}\right)$ experienced worldwide increases while showing different temporal change patterns (Fig. 2a and b). Eastern Europe, South America, southern Africa, and western Australia experienced warming combined with decreased precipitation, whereas southeast North America, western Europe, east Russia, and African rainforests experienced warming combined with increased precipitation. Meanwhile, net radiation increased in the equatorial tropics and arid regions in northwestern China, but decreased in the Arctic and Antarctic (Fig. 2c). The Palmer Drought Severity Index (PDSI) is a widely used index that correlates with soil moisture during warm seasons (Palmer, 1965; Dai, 2013). Global PDSI decreased at a rate of $-0.04 \mathrm{yr}^{-2}$ from 2000 to 2014, suggesting an increased risk of drought in the 21st century. Drought develops with periods of low-accumulated precipitation and is exacerbated by high temperatures. Warming-induced drying resulted from increased ET and was most prevalent. The spatial trend of PDSI shows that the eastern and northern coasts of North America, along with the African continent, Eurasia, and southern South America, exhibited obvious drought trends in 2000-2014. Northern China, parts of Mongolia, and western Russia near Lake Baikal also experienced a drying trend (Fig. 2d).

We analyzed partial correlations between NPP and temperature $(T)$, precipitation $(P)$, net radiation $\left(R_{\mathrm{n}}\right)$, and PDSI during growing seasons to determine their respective contributions across different regions (Fig. 3, Table 1).

In high latitudes of the $\mathrm{NH}\left(>47.5^{\circ} \mathrm{N}\right)$, temperature has a positive correlation with NPP $(R=0.6)$. Significant warming generally lengthens growing seasons for vegetation and promotes plant growth in tundra regions, so the recent warming in this region has increased NPP (Fig. 3a). In areas of high elevation such as the Tibetan Plateau (which is similar to high latitudes), temperature is the dominant control factor in vegetation growth. Climate changes have eased multiple climatic constraints to plant growth through earlier springs in some high latitudes, somewhat beneficial to plant growth, but the continuous warming may offset these benefits. For northern middle and low latitudes $\left(<47.5^{\circ} \mathrm{N}\right)$, where large areas are classified as having an arid climate, vegetation is shortrooted. NPP has a significant correlation with $P(R=0.7$, $p<0.05$ ) (Fig. 3b) and is also correlated to $R_{\mathrm{n}}$ (Fig. 3c).

Equatorial Amazon rainforests experienced significantly decreased NPP, whereas African rainforests exhibited an increasing trend. These changes in equatorial regions are mainly related to the warming in the Amazon along with increasing precipitation in African rainforests. High temperatures caused higher rates of ET, generally reducing soil water availability for vegetation in the Amazon.

In the $\mathrm{SH}$, we noted a significant correlation $(R=0.7$, $p<0.05$ ) between NPP and PDSI (Fig. 3d). The warming trend induced a much higher evaporative demand and led to a drying trend, except for the aforementioned increased precipitation in African rainforests. The PDSI in African rainforests also showed a slight increasing trend. A high $T$ value can increase both vapor pressure deficiency and moisture deficit and lead to a dryer environment. The general drought event across the $\mathrm{SH}$, which was induced by extreme heat and a precipitation deficit, has resulted in a net water availability reduction, ultimately reducing NPP. Hence, warmingassociated drying directly caused the significant decreasing trend of NPP in the SH. 
Table 1. Correlations between NPP and climatic variables for both hemispheres.

\begin{tabular}{llllll}
\hline Zones & NPP trend & $T$ trend & $P$ trend & $R_{\mathrm{n}}$ trend & PDSI trend \\
\hline NH high latitudes & $y=0.02 \times+30.51$ & $y=0.021 \times-5.75$ & $y=0.104 \times+46.58$ & $y=-5.21 \times+453.6$ & $y=-0.005 \times+0.23$ \\
$\left(>47.5^{\circ} \mathrm{N}\right)$ & & $R=0.60^{*}$ & $R=0.29$ & $R=0.45$ & $R=0.44$ \\
\hline NH mid/low & $y=0.07 \times+45.68$ & $y=0.009 \times+18.3$ & $y=0.341 \times+76.8$ & $y=3.239 \times+105.9$ & $y=0.006 \times-0.46$ \\
latitudes $\left(<47.5^{\circ} \mathrm{N}\right)$ & & $R=-0.17$ & $R=0.70^{* *}$ & $R=0.50$ & $R=0.56$ \\
\hline Southern Hemisphere & $y=-0.18 \times+78.37$ & $y=0.010 \times+21.6$ & $y=0.074 \times+116.8$ & $\begin{array}{l}y=2.455 \times+129.4 \\
R=-0.43\end{array}$ & $\begin{array}{l}2 \\
\end{array}$ \\
& & $R=-0.53$ & $R=0.37$ & $R=0.042 \times+0.33$ \\
& & & & $R=0.70^{* *}$ \\
\hline
\end{tabular}

* Significant at 0.05 level; ** significant at 0.01 level.

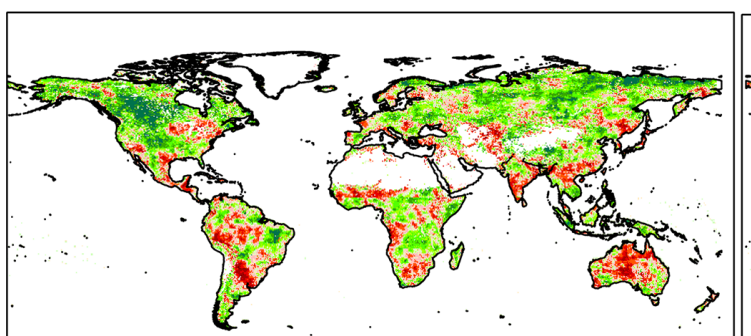

(a) Temperature

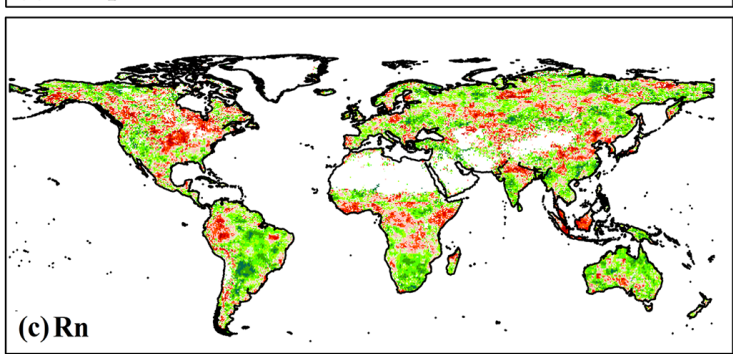

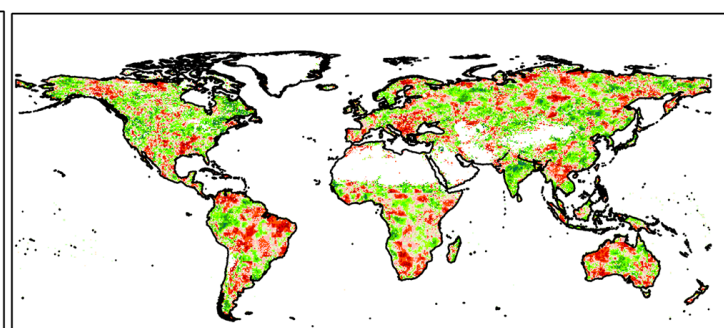

(b) Precipitation

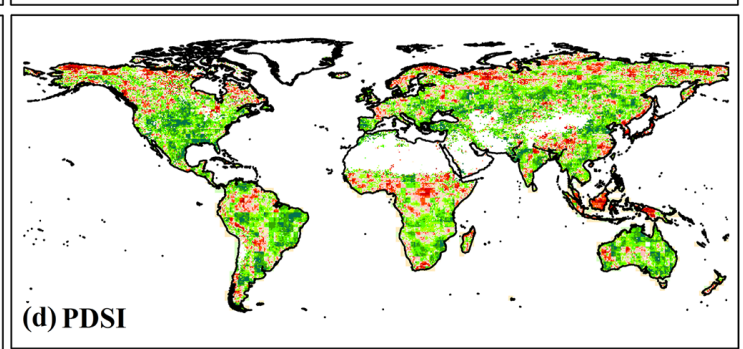

Correlations (2000-2014)

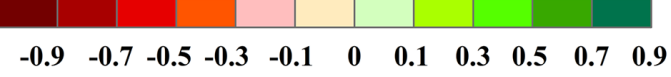

Figure 3. Partial correlations between NPP and (a) temperature, (b) precipitation, (c) net radiation, or (d) PDSI in growing season.

\subsection{Continued effects of NPP on evapotranspiration likely to exacerbate regional ecological droughts}

With respect to the impact of drought on the world's ecosystems, studies have been limited regarding the contribution of vegetation and terrestrial water cycle components to drought variations (Falloon et al., 2012; Teuling et al., 2013). However, the present lack of high-quality and long-term records of ET limit the forecasting of drought under climate change circumstances.

We used potential evapotranspiration (PET) as a surrogate measure of atmospheric moisture demand. PET is defined as the maximum quantity of water capable of being evaporated from soil and transpired from vegetation, whereas ET is the actual evaporation from water and soil, as well as transpiration from vegetation. Penman (1948) stated that ET had a proportional relationship with PET, and Bouchet (1963) hypothesized that a complementary feedback mechanism exists between ET and PET in water-limited regions. Overall, our investigation indicated that there is a proportional relationship between ET and PET in humid regions and a complementary one in arid regions (Figs. 1d and 4a). PET, as a surrogate measure of atmospheric moisture demand, has combined impacts of temperature, solar radiation, vapor pressure, and wind speed on its interaction with NPP (Fig. 4b). Over the past 15 years, global PET showed an increasing trend of $1.72 \mathrm{~mm} \mathrm{yr}^{-2}$, while global $P$ increased at a rate of $0.84 \mathrm{~mm} \mathrm{yr}^{-2}$. However, precipitation increases cannot offset evaporative demand, indicating a potential moisture deficit for water supplies constrained by ET. In other words, $P$ is mostly being lost to ET rather than being allocated to other components of the energy and water cycles (Zhang et al., 2015).

Various factors, including vegetation, affect the intensity and spatial variation of drought. Vegetation generally promotes land-atmosphere water exchange via transpiration, changing soil moisture conditions and affecting the landatmosphere feedback. Available soil moisture is defined as 

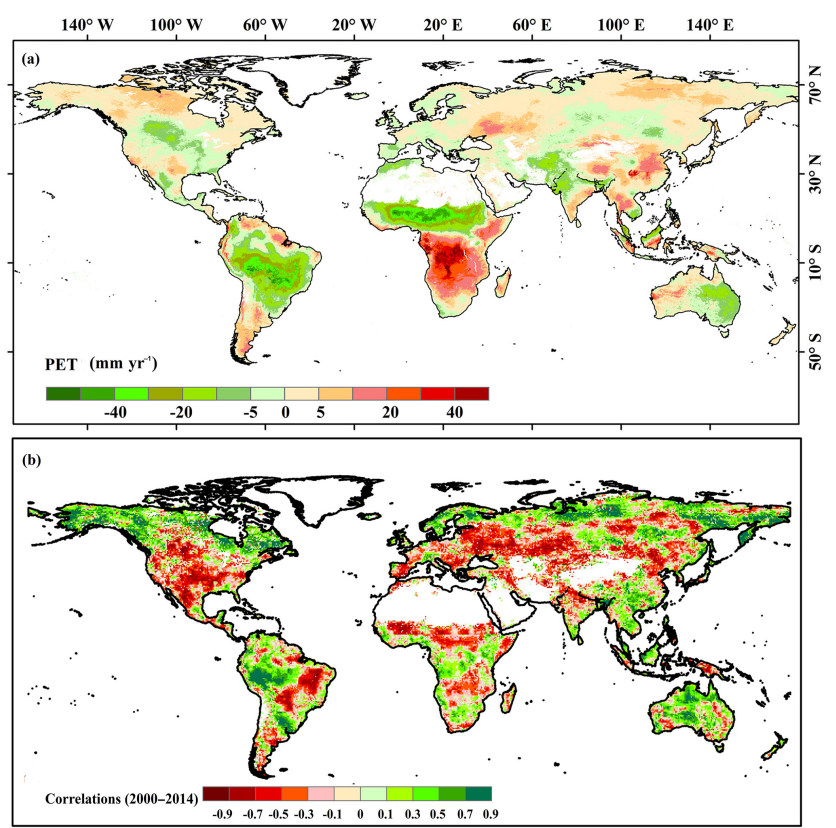

Figure 4. (a) Spatial pattern of PET trend. (b) Partial correlations between NPP and PET.

the amount of water a plant can access in its root zone. Thus, spatial and temporal variations in soil moisture are closely related to vegetation growth (Davis and Pelsor, 2001; Yang et al., 2010). Figure 5 illustrates the worldwide decrease in soil moisture of four layers (0-10, 10-40, 40-100, and 100$200 \mathrm{~cm}$ ). Soil moisture is an important sensor for measuring superficial wetness and dryness levels, and generally reflects the dryness and wetness of climate. Water vapor via transpiration can lead to increased regional atmospheric humidity over the short term, but preserve less water in the soil. Vegetation growth causes increased soil moisture evaporation, thus reducing the amount of soil water storage. This, in turn, accelerates reductions in soil moisture caused by warming. Especially in the areas where with less moisture conditions, as land-surface temperatures rise, increases in precipitation are insufficient to offset increases in evaporative demand, indicating a potential moisture deficit for water supplies constrained by ET. If low levels of soil moisture persist for long enough, reductions in vegetation cover and vigor can occur. This leads to soil water loss and reduced vegetation growth, along with higher risk of ecological drought (Meng et al., 2014; Zhang et al., 2015). Once vegetation suffers persistent drought, the vegetation biomass will rapidly decline and further intensify the ecological drought.

\section{Discussion}

Since the beginning of the 21st century, The Earth has experienced dramatic environmental changes. Strong variations in NPP and its effects on ET have been found worldwide in relation to significant alterations in climate. There are some uncertainties in the feedback of ecosystem responses to ET, but understanding the land-surface ecological feedback to atmospheric processes is necessary if we are to simulate climate change accurately. Several studies showed that relaxed climate constraints with increasing temperature and solar radiation sparked an increasing trend in global NPP in 19821999 (Nemani et al., 2003). This was followed by a droughtinduced reduction in global NPP in 2000-2009 (Zhao and Running, 2010). Our study showed that within the context of the past 15-year timeframe (which, as mentioned, was the warmest on record), the slightly increased interannual series of NPP and climate change promoted rises in global ET, thereby accelerating soil moisture loss. Weather systems can lead to droughts by suppressing precipitation (Beaumont et al., 2011) and by warming and drying soil via soiltemperature feedback (Seneviratne et al., 2010; Sheffield et al., 2012; Orlowsky and Seneviratne, 2013; Williams et al., 2014). Drought indices and precipitation-minus-evaporation readings suggest an increased risk of drought in the present century.

As noted previously, vegetation feeds back to the spatiotemporal characteristics of climate through ET. ET is a key process that dissipates the energy and water absorbed by vegetation and determines the diurnal cycle of near-surface temperature. It is limited mostly by energy in humid and semi-humid areas, whereas low-value ET is limited mostly by water in arid and semi-arid areas. Different values in climate conditions and variability as well as different land types will cause diverse changes in ET and its components (land surface evaporation, canopy evaporation, and transpiration). There are still major gaps in our understanding of how the responses of terrestrial ecosystems eliminate or increase the risk of dangerous climate change, and these gaps need to be filled. Steps towards better understanding the influence of human actions on terrestrial vegetation, e.g., differences in regional management for cropland and pastures are also needed.

\section{Conclusions}

The dramatic increase of global temperature since the year 2000 has a considerable impact on the global water cycle and rapidly alters the terrestrial vegetation dynamics. At the same time, vegetation variations also feedback to climate, and land ET is the means of this feedback.

The interannual series of global NPP slightly increased since 2000, but exhibited different changes in the Northern and Southern hemispheres. Over $64 \%$ of vegetated land areas experienced increased NPP in the NH, while $60.3 \%$ showed decreased NPP in the SH. In the NH, temperature was the dominant control factor for vegetation growth at high latitudes, and net radiation was the main factor affecting NPP at middle latitudes, while arid and semi-arid biomes were 

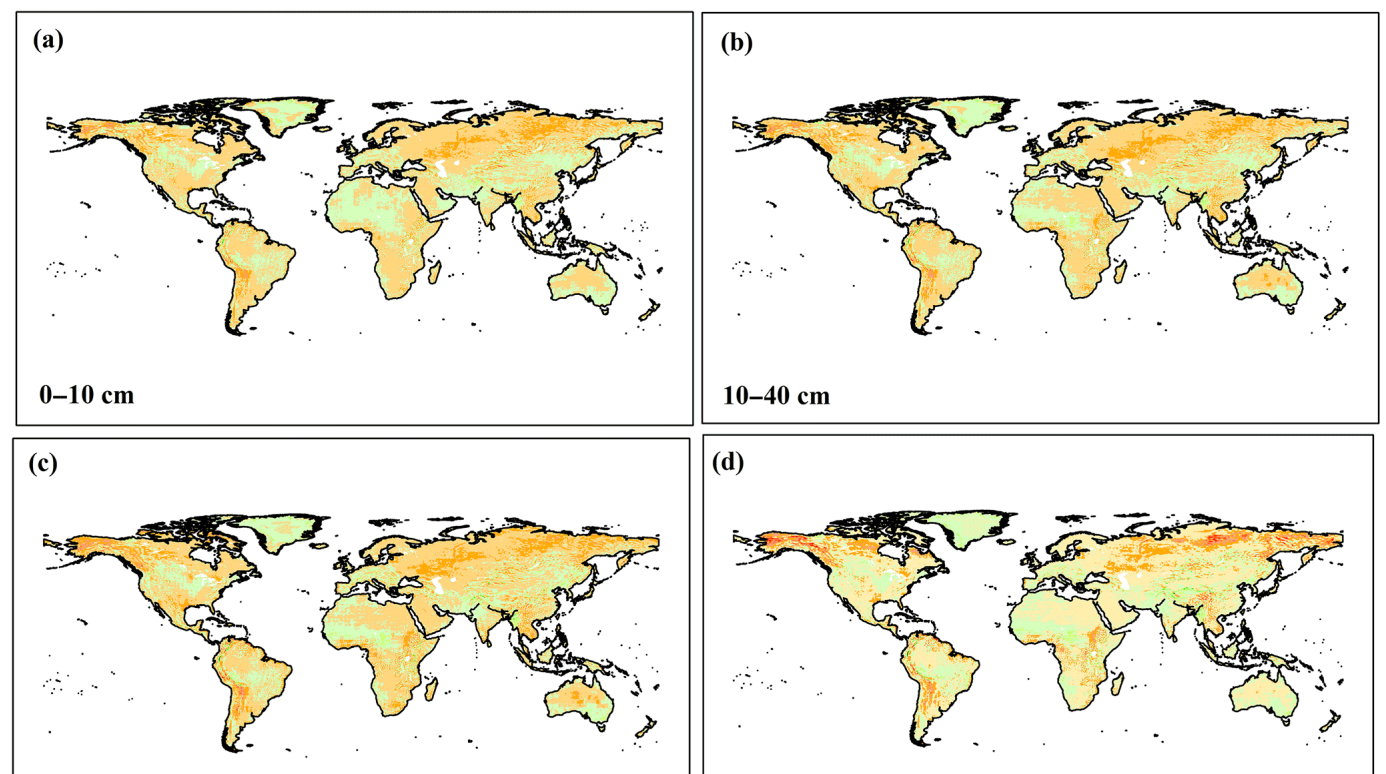

(d)

$40-100 \mathrm{~cm}$

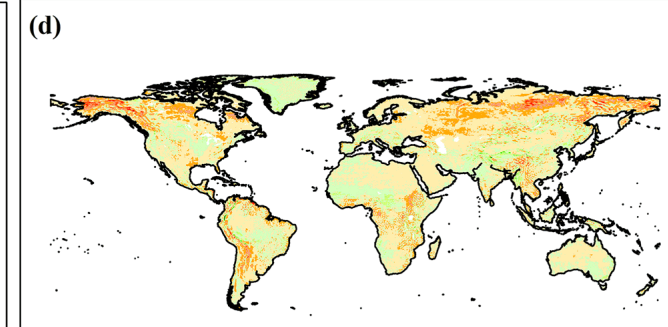

$100-200 \mathrm{~cm}$

Soil moisture $\left(\mathrm{kg} \mathrm{m}^{-2} \mathrm{yr}^{-1}\right)$

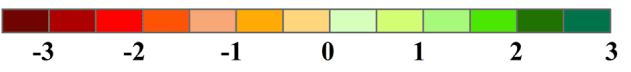

Figure 5. Trends of soil moisture in layers with different depths in 2000-2014.

mostly driven by precipitation. In the SH, NPP decreased due to warming-associated drying trends.

Vegetation greening and climate change promote rises of global ET. The rate of NPP to actual ET is likely to remain variable, specially, the increased rate of land ET in the $\mathrm{NH}$ $\left(0.61 \mathrm{~mm} \mathrm{yr}^{-2}\right)$ is faster than that in the SH $\left(0.41 \mathrm{~mm} \mathrm{yr}^{-2}\right)$. Over the same period, global warming and vegetation greening accelerate evaporation in soil moisture, thus reducing the amount of soil water storage. Continuation of these trends will likely exacerbate regional drought-induced disturbances and point to an increased risk of ecological drought, especially during regional dry climate phases.

\section{Data availability}

The monthly grid data of the temperature and precipitation series were collected from the Climatic Research Unit (CRUTS v3.23) (https://crudata.uea.ac.uk/cru/data/hrg/cru_ ts_3.23/cruts.1506241137.v3.23/). The radiation and soil moisture data series were issued by the Global Land Data Assimilation System (GLDAS-1) (http://gdata1.sci.gsfc.nasa. gov/daac-bin/G3/gui.cgi?instance_id=GLDAS025_M). The monthly data of the Palmer Drought Severity Index was available at http://www.cgd.ucar.edu/cas/catalog/climind/ pdsi.html. Global Land Cover Characterization data in 2000 was available at http://nsidc.org/data/ease/ancillary.html\# igbp_classes, along with MODIS in 2000 and 2013 (http:// modis.gsfc.nasa.gov/data/dataprod/mod12.php). The global
$1 \mathrm{~km}$ NPP datasets were available at http://www.ntsg.umt. edu/project/mod17\#data-product. And the MODIS evapotranspiration datasets were available at http://www.ntsg.umt. edu/project/mod16.

Author contributions. Zhi Li and Yaning Chen wrote the main manuscript text, Yang Wang and Gonghuan Fang prepared Figs. 4 and 6. All authors reviewed the manuscript.

Acknowledgements. The research is supported by the CAS "Light of West China" Program (2015-XBQN-B-17) and the Foundation of State Key Laboratory of Desert and Oasis Ecology (Y471166).

Edited by: Q. Chen

\section{References}

Beaumont, L. J., Pitman, A., Perkins, S., Zimmermann, N. E., Yoccoz, N. G., and Thuiller, W.: Impacts of climate change on the world's most exceptional ecoregions, P. Natl. Acad. Sci. USA., 108, 2306-2311, doi:10.1073/pnas.1007217108, 2011.

Beer, C., Reichstein, M., Tomelleri, E., Ciais, P., Jung, M., Carvalhais, N., Rödenbeck, C., Arain, M. A., Baldocchi, D., Bonan, G. B., Bondeau, A., Cescatti, A., Lasslop, G., Lindroth, A., Lomas, M., Luyssaert, S., Margolis, H., Oleson, K. W., Roupsard, O., Veenendaal, E., Viovy, N., Williams, C., Woodward, F. I., and 
Papale, D.: Terrestrial gross carbon dioxide uptake: global distribution and covariation with climate, Science, 329, 834-838, doi:10.1126/science.1184984, 2010.

Bouchet, R. J.: Evapotranspiration reele et potentielle, signification climatique, General Assembly of Berkeley, Red Book, 62, IAHS, Gentbrugge, Belgium, 134-142, 1963.

Chapin, F. S., Matson, P. A., and Vitousek, P. M.: Principles of terrestrial ecosystem ecology, Springer, New York, 32 pp., 2011.

Chen, G. S., Tian, H. Q., Zhang, C., Liu, M. L., Ren, W., Zhu, W. Q., Chappelka, A. H., Prior, S. A., and Lockaby, G. B.: Drought in the Southern United States over the 20th century: Variability and its impacts on terrestrial ecosystem productivity and carbon storage, Climatic Change, 114, 379-397, doi:10.1007/s10584-0120410-z, 2012.

Chen, L. Y., Li, H., Zhang, P. J., Zhao, X., Zhou, L. H., Liu, T. Y., Hu, H. F., Bai, Y. F., Shen, H. H., and Fang, J. Y.: Climate and native grassland vegetation as drivers of the community structures of shrub-encroached grasslands in Inner Mongolia, China, Landscape Ecol., 30, 1627-1641, doi:10.1007/s10980-014-0044-9, 2015.

Chen, Y. K., Yang, J., Qin, L., Tang, W. Z., and Han, M.: Evaluation of AMSR-E retrievals and GLDAS simulations against observations of a soil moisture network on the central Tibetan Plateau, J. Geophys. Res., 118, 4466-4475, doi:10.1002/jgrd.50301, 2013.

Dai, A. G.: Increasing drought under global warming in observations and models, Nat. Clim. Change, 3, 52-58, doi:10.1038/nclimate1633, 2013.

Dai, A. G., Trenberth, K. E., and Qian, T. T.: A global dataset of Palmer Drought Severity Index for 1870-2002: relationship with soil moisture and effects of surface warming, J. Hydrometeorol., 5, 1117-1130, doi:10.1175/JHM-386.1, 2004.

Davie, J. C. S., Falloon, P. D., Kahana, R., Dankers, R., Betts, R., Portmann, F. T., Wisser, D., Clark, D. B., Ito, A., Masaki, Y., Nishina, K., Fekete, B., Tessler, Z., Wada, Y., Liu, X., Tang, Q., Hagemann, S., Stacke, T., Pavlick, R., Schaphoff, S., Gosling, S. N., Franssen, W., and Arnell, N.: Comparing projections of future changes in runoff from hydrological and biome models in ISI-MIP, Earth Syst. Dynam., 4, 359-374, doi:10.5194/esd-4359-2013, 2013.

Davis, M. A. and Pelsor, M.: Experimental support for a resourcebased mechanistic model of invisibility, Ecol. Lett., 4, 421-428, doi:10.1046/j.1461-0248.2001.00246.x, 2001.

Douville, H., Ribes, A., Decharme, B., Alkama, R., and Sheffield, J.: Anthropogenic influence on multidecadal changes in reconstructed global evapotranspiration, Nat. Clim. Change, 3, 59-62, doi:10.1038/NCLIMATE1632, 2013.

Falloon, P. D., Dankers, R., Betts, R. A., Jones, C. D., Booth, B. B. B., and Lambert, F. H.: Role of vegetation change in future climate under the A1B scenario and a climate stabilisation scenario, using the HadCM3C Earth system model, Biogeosciences, 9, 4739-4756, doi:10.5194/bg-9-4739-2012, 2012.

Field, C. B., Lobell, D. B., Peters, H. A., and Chiariello, N. R.: Feedbacks of terrestrial ecosystems to climate change, Annu. Rev. Environ. Resour., 32, 1-29, doi:10.1146/annurev.energy.32.053006.141119, 2007.

Friedl, M. A., Sulla-Menashe, D., Tan, B., Schneider, A., Ramankutty, N., Sibley, A., and Huang, X. M.: MODIS Collection 5 global land cover: Algorithm refinements and character- ization of new datasets, Remote Sens. Environ., 114, 168-182, doi:10.1016/j.rse.2009.08.016, 2010.

Gang, C. C., Wang, Z. Q., Zhou, W., Chen, Y. Z., Li, J. L., Cheng, J. M., Guo, L., Odeh, I., and Chen, C.: Projecting the dynamics of terrestrial net primary productivity in response to future climate change under the RCP2.6 scenario, Environ. Earth Sci., 74, 5949-5959, doi:10.1007/s12665-015-4618-x, 2015.

Hughes, R. F., Archer, S. R., Asner, G. P., Wessman, C. A., McMurtry, C., Nelson, J., and Ansley, R. J.: Changes in aboveground primary production and carbon and nitrogen pools accompanying woody plant encroachment in a temperate savanna, Global Change Biol., 12, 1733-1747, doi:10.1111/j.13652486.2006.01210.x, 2006.

Ito, A.: A historical meta-analysis of global terrestrial net primary productivity: Are estimates converging, Global Change Biol., 17, 3161-3175, doi:10.1111/j.1365-2486.2011.02450.x, 2011.

Jung, M., Reichstein, M., Ciais, P., Seneviratne, S. I., Sheffield, J., Goulden, M. L., Bonan, G., Cescatti, A., Chen, J. Q., de Jeu, R., Dolman, A. J., Eugster, W., Gerten, D., Gianelle, D., Gobron, N., Heinke, J., Kimball, J., Law, B. E., Montagnani, L., Mu, Q. Z., Mueller, B., Oleson, K., Papale, D., Richardson, A. D., Roupsard, O., Running, S., Tomelleri, E., Viovy, N., Weber, U., Williams, G., Wood, E., Zaehle, S., and Zhang, K.: Recent decline in the global land evapotranspiration trend due to limited moisture supply, Nature, 467, 951-954, doi:10.1038/nature09396, 2010.

Li, Z., Chen, Y. N., Li, W. H., Deng, H. J., and Fang, G. H.: Potential impacts of climate change on vegetation dynamics in Central Asia, J. Geophys. Res., 120, 12345-12356, doi:10.1002/2015JD023618, 2015.

Matsui, T., Lakshmi, V., and Small, E. E.: The effects of satellite-derived vegetation cover variability on simulated landatmosphere interactions in the NAMS, J. Climate, 18, 21-40, doi:10.1175/JCLI3254.1, 2005.

Meng, X. H., Evans, J. P., and McCabe, M. F.: The impact of observed vegetation changes on land-atmosphere feedbacks during drought, J. Hydrometeorol., 15, 759-776, doi:10.1175/JHM-D13-0130.1, 2014.

Mu, Q., Heinsch, F. A., Zhao, M., and Running, S. W.: Development of a global evapotranspiration algorithm based on MODIS and global meteorology data, Remote Sens. Environ., 111, 519-536, doi:10.1016/j.rse.2007.04.015, 2007.

Mu, Q., Zhao, M., and Running, S. W.: Improvements to a MODIS global terrestrial evapotranspiration algorithm, Remote Sens. Environ., 115, 1781-1800, doi:10.1016/j.rse.2011.02.019, 2011.

Myneni, R. B., Hoffman, S., Knyazikhin, Y., Privette, J. L., Glassy, J., Tian, Y., Wang, Y., Song, X., Zhang, Y., Smith, G. R., Lotsch, A., Friedl, M., Morisette, J. T., Votava, P., Nemani, R. R., and Running, S. W.: Global products of vegetation leaf area and fraction absorbed PAR from year one of MODIS data, Remote Sens. Environ., 83, 214-231, 2002.

Nemani, R. R., Keeling, C. D., Hashimoto, H., Jolly, W. M., Piper, S. C., Tucker, C. J., Myneni, R. B., and Running, S. W.: Climate-driven increases in global terrestrial net primary production from 1982 to 1999 , Science, 300, 1560-1563, doi:10.1126/science.1082750, 2003.

Neumann, M., Zhao, M. S., Kindermann, G., and Hasenauer, H.: Comparing MODIS net primary production estimates with ter- 
restrial national forest inventory data in Austria, Remote Sens., 7, 3878-3906, doi:10.3390/rs70403878, 2015.

Orlowsky, B. and Seneviratne, S. I.: Elusive drought: uncertainty in observed trends and short- and long-term CMIP5 projections, Hydrol. Earth Syst. Sci., 17, 1765-1781, doi:10.5194/hess-171765-2013, 2013.

Pan, S. F., Tian, H. Q., Dangal, S. R., Zhang, C., Yang, J., Tao, B., Ouyang, Z. Y., Wang, X. K., Lu, C. Q., Ren, W., Banger, K., Yang, Q. C., Zhang, B. W., and Li, X.: Complex spatiotemporal responses of global terrestrial primary production to climate change and increasing atmospheric $\mathrm{CO}_{2}$ in the 21 st century, PloS One, 9, e112810, doi:10.1371/journal.pone.0112810, 2014.

Palmer, W. C.: Meteorological Drought, US Dep. of Commer., Weather Bur., Washington, D.C. 6-8, 1965.

Penman, H. L.: Natural evaporation from open water, bare and grass, P. Roy. Soc. Lond., 193, 120-145, 1948.

Potter, C. S., Klooster, S., and Genovese, V.: Net primary production of terrestrial ecosystems from 2000 to 2009, Climatic Change, 115, 365-378, doi:10.1007/s10584-012-0460-2, 2012.

Seneviratne, S. I., Corti, T., Davin, E. L., Hirschi, M., Jaeger, E. B., Lehner, I., Orlowsky, B., and Teuling, A. J.: Investigating soil moisture-climate interactions in a changing climate: A review, Earth-Sci. Rev., 99, 125-161, doi:10.1016/j.earscirev.2010.02.004, 2010.

Sheffield, J., Wood, E. F., and Roderick, M. L.: Little change in global drought over the past 60 years, Nature, 491, 435-438, doi:10.1038/nature11575, 2012.

Shen, M. G., Piao, S. L., Jeong, S. J., Zhou, L. M., Zeng, Z. Z., Ciais, P., Chen, D. L., Huang, M. T., Jin, C. S., Li, L. Z. X., Li, Y., Myneni, R. B., Yang, K., Zhang, G., Zhang, Y. J., and Yao, T. D.: Evaporative cooling over the Tibetan Plateau induced by vegetation growth, P. Natl. Acad. Sci. USA, 112, 9299-9304, doi:10.1073/pnas.1504418112, 2015.

Teuling, A. J., van Loon, A. F., Seneviratne, S. I., Lehner, I., Aubinet, M., Heinesch, B., Bernhofer, C., Grünwald, T., Prasse, H., and Spank, U.: Evapotranspiration amplifies European summer drought, Geophys. Res. Lett., 40, 2071-2075, doi:10.1002/grl.50495, 2013.

Tian, H., Melillo, J., Kicklighter, D., McGuire, A. D., Iii, J. H., Iii, B. M., and Vörösmarty, C. J.: Climatic and biotic controls on annual carbon storage in Amazonian ecosystems, Global Ecol. Biogeogr., 9, 315-335, doi:10.1046/j.1365-2699.2000.00198.x, 2000 .
University of East Anglia Climatic Research Unit, Harris, I., and Jones, P. D.: Climatic Research Unit (CRU) Time-Series (TS) Version 3.23 of High Resolution Gridded Data of Month-bymonth Variation in Climate (Jan. 1901-Dec. 2014), Centre for Environmental Data Analysis, doi:10.5285/4c7fdfa6-f176-4c58acee-683d5e9d2ed5, 2015.

Wentz, F. J., Ricciardulli, L., Hilburn, K., and Mears, C.: How much more rain will global warming bring?, Science, 317, 233-235, doi:10.1126/science.1140746, 2007.

Williams, I. N., Torn, M. S., Riley, W. J., and Wehner, M. F.: Impacts of climate extremes on gross primary production under global warming, Environ. Res. Lett., 9, 094011, doi:10.1088/17489326/9/9/094011, 2014.

Yang, Y. H., Fang, J. Y., Ma, W. H., Smith, P., Mohammat, A., Wang, S. P., and Wang, W.: Soil carbon stock and its changes in northern China's grasslands from 1980s to 2000s, Global Change Biol., 16, 3036-3047, doi:10.1111/j.1365-2486.2009.02123.x, 2010.

Zhang, J., Wang, W. C., and Wei, J.: Assessing land-atmosphere coupling using soil moisture from the Global Land Data Assimilation System and observational precipitation, J. Geophys. Res., 113, D17119, doi:10.1029/2008JD009807, 2008.

Zhang, K., Kimball, J. S., Nemani, R. R., Running, S. W., Hong, Y., Gourley, J. J., and Yu, Z. B.: Vegetation greening and climate change promote multidecadal rises of global land evapotranspiration, Sci. Rep., 5, 15956, doi:10.1038/srep15956, 2015.

Zhao, M. S. and Running, S. W.: Drought-induced reduction in global terrestrial net primary production from 2000 through 2009, Science, 329, 940-943, doi:10.1126/science.1192666, 2010.

Zhi, H., Wang, P. X., Dan, L., Yu, Y. Q., Xu, Y. F., and Zheng, W. P.: Climate-vegetation interannual variability in a coupled atmosphere-ocean-land model, Adv. Atmos. Sci., 26, 599-612, doi:10.1007/s00376-009-0599-6, 2009. 